\title{
'Rock'n'roll was everywhere': Youth culture history as heritage tourism on Queensland's Gold Coast
}

\author{
Christine Feldman-Barrett \\ c.barrett@griffith.edu.au
}

\begin{abstract}
Historically, the Gold Coast is a 'young' city and urban area inextricably tied to tourism, and a reputation for sun and surf. While this is undeniably true, another lesser known narrative bound to music-driven youth culture from the 1960 s to the 1980s is also part of the Gold Coast's history. With 'heritage tourism' linked to popular music in recent years, this article examines how the Gold Coast's youth culture history may potentially inform new tourist practices in the country's sixth largest city. Regardless of whether such heritage tourism is ever adopted by the Gold Coast's governing bodies, mapping this relationship between music, youth and place offers a new perspective on an active Australian city- one often stereotyped as a place with a penchant for erasing its past and only looking to the future.
\end{abstract}

While many stereotypes are attached to Queensland's Gold Coast, the notion of it as a dynamic site within Australian youth culture history is not usually one of them. The sprawl of its interconnected beach towns has prompted many Queenslanders, other Australians and international visitors to view the country's sixth-largest metropolitan area as a place of sun, sand, surf and little else (Griffin 1998: 286). Given its modern origins as the country's premier tourist mecca, considerable attention has been paid to the Gold Coast's image in regards to its urban development. With a history that popularly starts in the twentieth century, it is little wonder that this 'young' city has been described as going through its 'adolescence' (Burton 2012: 8). Given its 'youthfulness' and a contemporary nightclub scene popular with many young people today, it should be unsurprising that the Gold Coast has a rich youth culture history connected to music-based leisure practices. This narrative not only helps depict a more nuanced view of the Gold Coast, but it could offer contemporary opportunities within heritage tourism.

Over the past several decades, the Gold Coast's cultural and political players have realised that the city cannot survive and thrive in the long term on beachrelated tourism alone (Griffin 1998: 287; Beesley 2005). Some efforts have already been made to incorporate historic aspects of the city's cultural life into events and spaces that can be enjoyed by both tourists and city residents. A good example is the 
1950s-themed Wintersun Festival, which ran in Coolangatta from 1985 to 2010 and reimagined what local youth culture was like in the heyday of rock'n'roll. As Weaver (2010: 255) explains, 'one of the objectives of the festival [was] to establish a year round tourism nostalgia theme for Coolangatta'. Similarly, the Surf World museum and the Bleach Festival both celebrate what was, and continues to be, one of the city's main subcultural identities: the surfer (Baker, Bennett and Wise 2012: 101; Evers 2009). Although the latter example depicts a more familiar narrative of the city as a 'surfer's paradise', it nonetheless also illustrates the Gold Coast's potential for 'heritage tourism', whereby visitors would be drawn to sites and activities linked to a locale's socio-historic significance (Poria, Butler and Airey 2001).

Two US cities with similar trajectories to that of the Gold Coast, Las Vegas and Miami, have long celebrated their tourist pasts as important markers of twentiethcentury culture. This is apparent in the form of Las Vegas's Neon Sign museum and Miami's restoration of South Beach's pastel-coloured art deco buildings. Unfortunately, such initiatives are more challenging on the Gold Coast, as the city has suffered from ambitious developers and rampant demolitions, that have razed many a would-be modernist, pop culture treasure (Stoltz 2013; Weaver 2011). Furthermore, while there is certainly more to the Gold Coast's cultural history than a catalogue of 'wild weekends', that narrative is still an integral aspect of the city's heritage, and should not be hidden away like a shameful secret. Unlike the abovementioned American cities, which readily embrace all aspects of their past, those who determine the Gold Coast's urban planning and tourism have yet to fully do this.

Considering this image of the Gold Coast as a site of leisure and consumption par excellence, it is interesting to note that its music-driven, youth-culture history has mostly been overlooked. However, when reviewing the contemporary history of this Queensland city, it soon becomes clear that it has been a key location for music-based youth culture in Australia. Because of this, it has the potential to be an attractive site for heritage tourism. This is specifically tied to the role played by its myriad music venues for young people from the 1960s through the 1980s (Arrow 2009: 91, 127). Such knowledge provides room to discuss how cultural tourism on the Gold Coast could celebrate this history. However, in order to discuss the Gold Coast's musical past and its potential contribution to the present, it is important to pay attention to the relationship between music and place and, more specifically, the concept of popular music heritage and how it has developed elsewhere.

\section{Popular music, youth and narratives of place}

Since the 1990s, scholarship has developed that examines the relationship between popular music, youth culture and geographic space. This research is usually situated in disciplines such as musicology, sociology and geography (Nayak 2003; Skelton and Valentine 1996; Whiteley, Bennett and Hawkins 2005). Sara Cohen (1991, 2013), for instance, examines how the Beatles and the 1960s Merseybeat phenomenon, as well as more recent music scenes, have influenced the city of Liverpool. John Connell and Chris Gibson's Sound Tracks: Popular Music, Identity and Place (2002) offers many international examples showcasing the connection between music and locale. They assert (2002: 6) that 'many everyday understandings 
about places (whether particular sites such as concerts or festival venues, regions with music traditions, or national institutions) are mediated through engagements with popular music'.

Similarly, Johansson and Bell's (2009) collection Sound, Society, and the Geography of Popular Music examines the multiple interpretations of place as viewed through music and its many histories One chapter, Kevin Romig's (2009) 'A Listener's Mental Map of California', argues that preconceived notions of California have been influenced by competing visions of the state via the hit songs about it. The early song catalogue of the Beach Boys, for instance, suggests that southern California, much like the Gold Coast, is simply about sun and surf. However, by 1967 , when the Bay Area became home to the 1960s counterculture, Scott MacKenzie's song 'If You're Going to San Francisco (Be Sure to Wear Flowers in Your Hair)', altered listeners' perceptions of the state. Although California has never just been about enjoying sun and surf or being a hippie, these songs continue to evoke certain associations in its listeners (Romig 2009). Deborah Che's (2009) 'Techno: Music and Entrepreneurship in Post-Fordist Detroit' examines how the city's popular music history from 1960s Motown to early 1970s proto-punk laid the groundwork and cultivated entrepreneurship more generally and popular music tourism specifically. This blossomed through the city's techno scene in the 1980s and 1990s. In an otherwise economically downtrodden city, local popular music and its history have played an influential role in Detroit's attempts at revitalisation. Like Sara Cohen's (2007) Decline, Renewal and the City in Popular Music Culture: Beyond the Beatles, Che's study emphasises how popular music can nourish and enliven cities whose once modernist narrative of industrial might has long since collapsed.

The fact that these examples mostly reflect the musical sensibilities of the baby boom generation is not serendipitous. According to Andy Bennett (2009: 478), the institutionalisation of rock music from the 1960s and 1970s helps make 'music of [the baby boomers'] youth ... a fundamental aspect of the late twentieth century cultural heritage'. This type of heritage informs tourism, and may include city tours focused on a band, performer or popular music genre, commemoration festivals, tribute or cover bands, plaques or statues memorialising key sites and musical theme-nights featuring, for instance, Motown or the Merseybeat sound. The fact that Beatles tourism is still essential to Liverpool's current vitality, or that fans of the Supremes or the Four Tops can tour the building where Motown's hits were recorded, suggests that much of today's popular music heritage and affiliated tourism have been created by and for people who were teenagers and young adults during the 1960s. Nonetheless, such sites are not only enjoyed by baby boomers, but also are popular with younger cohorts. Through the recycling of 1960s images and sounds in various media forms, subsequent generations have adopted aspects of classic baby boom culture as their own. Or, to cite Coupland (1991: 41), it is a kind of 'legislated nostalgia', which enables younger generations to also be knowledgeable about 1960s music and culture.

However, since Generation X has entered middle age, it is clear that the 1980s and the 1990s, have become loci for another wave of nostalgia. For instance, many of today's 1960s enthusiasts joined the mod subculture in the 1980s and 1990s, and are now keen to relive their youth by holding events at venues not necessarily popular in the 1960s — the original era of mod - but at those from their teenage 
years (Feldman 2009). Journalist Simon Reynolds also points out that there is a constant recycling of popular culture, which initially focused on the 1960s (during the late 1970s to the mid-1990s), but now includes the 1970s, 1980s and 1990s. He claims that MTV's repeated airing of I Love the 80s and I Love the 90s over the last ten years is just one example of this phenomenon (2011: xix). Thus, regarding the possibilities of heritage tourism linked to music-driven youth culture history in various locales, more opportunities can arise with each ageing generational cohort.

\section{Youth culture heritage as tourism}

Given this discourse about popular music and youth culture 'heritage' and its relationship with place, entrepreneurs may also think about how music-driven youth culture histories can potentially inform tourism strategies. Beyond the aforementioned examples from Liverpool and Detroit, two further instances include a punk tour of New York City and a trail of do-it-yourself (DIY) indie rock sites to explore in Portland, Oregon. In New York, an 'East Village Rock and Punk Tour' shows interested parties where the Ramones spent time and where the infamous CBGB nightclub was housed until its 2006 closure (Kugel 2008). Portland has been called 'America's indie rock theme park', since many musicians of this genre - most of whom found fame in the 1990s - still live there. This means that the city offers sites teeming with more recent popular music history. Music tourists will visit nightclubs, cafes and music shops frequented by local residents, who are also luminaries within the indie rock scene. The temporal proximity to a still ongoing and vibrant scene 'entrenched in juvenilia', to quote indie musician Carrie Brownstein, offers a kind of history-in-the-making tourism that parallels similar treks to 'Swinging London' made by trendy young people during the mid-1960s (Clark 2005; Halasz 1967).

Not far from Portland is Seattle, the birthplace of 1960s icon Jimi Hendrix and the 1990s grunge music genre. More conventionally, the city touts heritage tourism through the Experience Music Project museum. Appropriately, it hosted an exhibit called Nirvana: Taking Punk to the Masses in 2011 to mark the twentieth anniversary of the band's breakthrough album Nevermind (Cross 2011). Grunge fans can also participate in 'Stalking Seattle', which is a 'Rock and Roll Sightseeing Tour' of the city. According to its website, participants can 'see the first place Pearl Jam played, the bar where Nirvana played to nobody, the Jimi Hendrix statue, all important clubs and theatres, the home where Kurt Cobain lived and died, filming locations from the movie Singles and much more' (Stalking Seattle home page). Clearly, many of the stops along this tour are venues where grunge bands once performed.

Popular music and youth culture heritage sites and their adherent tourist offerings are not limited to developed countries or exclusively urban settings. Jamaica's tourism profoundly changed in the 1970s and 1980s as a result both of musician Bob Marley's global success and his premature death in 1981. Reggae music and the idyll of a relaxed, Rastafarian subculture have become key selling points for a nation that in its early history, and not unlike Australia's Gold Coast, marketed itself as a beach-based resort destination. Promoting Jamaica as the land of reggae and 'Rastas' has also helped to keep potential tourists focused on the positive 
attributes of the country rather than on its poverty and crime (King and Foster 2001).

In all these examples, the connection between popular music, youth culture and tourism is based primarily on the relationship between key musical performers or genres and those places attached to them. This is illustrated most obviously by tourism in Liverpool, Detroit and Jamaica - the homes of the Beatles, Motown and reggae respectively. However, as the examples of New York, Portland and Seattle demonstrate, such sightseeing can also include visiting key venues where music-oriented youth culture scenes once coalesced and blossomed. It is with these examples in mind that the history of a music-driven youth culture on the Gold Coast could provide a new kind of heritage tourism there.

\section{A Gold Coast history: Youth and popular music}

In the 1960s, while skyscrapers started to proliferate along the city's coastline, another narrative was unfolding. It had less to do with the Gold Coast's localised, beach-oriented tourism per se than with its connection to the youth and rock music culture developing nationwide by 1964 . This year was an important, transitional one in youth culture history for many developed countries like Australia due to the breakthrough success of the Beatles. Jon Stratton (1992: 9) suggests that the country's dominant youth subcultures of the 1950s and early 1960s, the Bodgies, Widgies and surfers, were suddenly overshadowed by the mod sensibility adopted and modelled by the Beatles. Connell and Gibson (2002: 57) chronicle the ecstatic reception the band received that year during its Australian tour. They write that, especially during an era when few international acts toured the Southern Hemisphere, the Beatles were welcomed by staggeringly large crowds. Zion (1987) claims that this reception - particularly the one in Adelaide - was also an effect of the substantial youth population that had recently emigrated from Britain.

As a result of the Beatles' and (soon) other British acts' influence, a cavalcade of homegrown bands formed and, in doing so, helped establish a mod-oriented youth scene in Australia. English-born and Canberra-raised musician Steve Kilbey describes the enthusiasm that such groups stirred among Australian youth: 'The first thing I ever saw was a package tour with Normie Rowe and the Easybeats and MPD Limited and Bobbi and Laurie ... and everybody [in the audience] was stomping on the floor and it was amazing' (The Church 2010). In Kilbey's estimation, Australia was never musically a 'poor relation' to Britain or the United States, but an equal in quality and passion. While bands such as the Missing Links, the Masters Apprentices, the Throb, the Loved Ones and the Aztecs were promoted nationwide through live shows, coverage in print media and on TV shows, most groups were still primarily from Sydney or Melbourne, with a substantial number also coming from Adelaide (Arrow 2009: 90-93; Marks and McIntyre 2011; McIntyre 2006).

In this mapping of mod-era music, it appears that Queensland has been underrepresented in this history of popular music production. While the British-born and not yet famous Bee Gees left the beachy Brisbane suburb of Redcliffe and returned to England by 1967, a group called the Purple Hearts formed and gigged through the city. However, they too eventually moved away to Melbourne. Prior to the election of Joh Bjelke-Petersen as Queensland's premier in 1968 - an election that 
would have lasting cultural effects on the state for years to come - Brisbane actually did offer young adults a good number of venues for live music. According to the Purple Hearts' Lobby Loyde, 'Queensland was pretty progressive. I mean, the little clubs everywhere in Brisbane had blues and rock'n'roll. The Blues Club was always a big thing up there' (Marks and McIntyre 2011: 150). By 1968, though, things were changing as a result of Queensland's new leadership. As Andrew Stafford (2004: 15) documents in Pig City, by the late 1960s 'the city simply shut down on the weekends ... For young people the prevailing atmosphere was a fetid, fermenting mixture of enervating heat, boredom and unrelieved tension.' While Brisbane felt much of the brunt of the seemingly anti-youth and anti-fun BjelkePetersen government, Gold Coast establishments continued to hire bands to play various venues - primarily in Surfers Paradise and Coolangatta - often for weekor month-long engagements (The Creatures n.d.; Wind and Sea 2011).

Despite a growing understanding of Brisbane's youth culture past through books like Pig City, such a history of the Gold Coast remains mostly undocumented. However, George Farwell's 1970 book Sun Country offers a vivid impression of how popular music and youth culture insinuated themselves into the cityscape. He writes, 'This is part of the with-it scene, the folk, rock and pop belting out day and night from metallic loudspeakers on streets and beach ... Surfers is pop art brought out on the streets ... [with] ... the sound of mod music' (1970: 78). More recently, the Gold Coast Bulletin ran a story entitled 'Born to Be Wild', where singer and long-time Gold Coast resident Mary-Anne Sterling shares memories of the city's rock music past. What she discloses illustrates a 'happening' scene that, in her mind, trumped those of other Australian cities at the time:

From about 1967 I just lived for Cavill Avenue. It was the centre of the world for a singer like me and for rock'n'roll fans all over the Coast. It was like Las Vegas, the Gold Coast was, with clubs and musicians and bands and audiences from Coolangatta to Southport ... Yeah, it was just like Las Vegas. Rock'n'roll was everywhere. If you didn't like one place you could go next door and there'd be a different band playing, and one next door to that, and one across the street and so on. Sure, the Gold Coast was all about the sun and the beach and all that. But for me, and for plenty of others, it was about the music. (Jacobson 2009)

Sterling recounts seeing the Creatures, who sported different-coloured, pageboylength hair, and lived and performed on the Gold Coast for an extended period in 1967. According to another source, the group acquired such a large following there that it eventually opened a club in Surfers Paradise called 'Op-a-Go-Go' before eventually moving to Sydney (The Creatures, n.d.).

The Creatures' nightclub was just one of many that thrived in the Gold Coast during the mid-to late 1960s. Others included the Take Five Club, El Rancho, the Red Orb and the Summit, the last of which was a nightclub positioned at the top of the Paradise Towers (Jacobson 2009). This robust scene enticed many youths to make weekend drives from Brisbane to the Gold Coast. Brisbane native and retired professor Pat Buckridge remembers preferring events and youth-oriented music spaces available to him and his friends on the Gold Coast to those in Brisbane. According to him, barring a few 'sound lounges' around Brisbane - which were precursors to nightclubs or discos - there was more 'excitement ... and 
interactivity' to be had at concerts and parties hosted at Gold Coast venues (Buckridge 2012).

Archival information on these now-defunct clubs is scant, but their existence for both performers and audiences alike remains an important contributing factor to Australia's popular music scene. As Arrow (2009: 91) observes, 'Australian bands were increasingly sustained by mutually dependent local music scenes: youth media promoted bands, who attracted audiences to venues, which cultivated informal dress codes that youth could match by shopping in boutiques that were often advertised in youth media and so on.' Therefore, while Melbourne, Sydney and Adelaide may have produced most of the acts of the era, the Gold Coast's vibrant nightlife set an exceptional scene for young people's engagement with popular music.

The Gold Coast remained a hub for popular music consumption with the next generation - albeit with a new set of nightclubs. By the 1980s, a time when Australian music came into its own due to more international attention through bands like Men at Work and INXS, clubs like Surfers Paradise's Bombay Rock, Currumbin's Playroom and Coolangatta's Jet Club became key venues to experience this new wave of youth culture. National acts like the Divinyls and Cold Chisel, as well as foreign groups like the Cure and the Dead Kennedys, drew youthful audiences from not only the Gold Coast or northern New South Wales, but also from Brisbane, where the destruction and closure of venues such as Cloudland had become commonplace (Baker 1987; Gough 2014; Stafford 2004).

The now-defunct Bombay Rock was an especially favoured venue during the 1980s, and featured bands and performers from across the globe. Writer and Actor Nikki McWatters (2012), who grew up on the Gold Coast, frequented the Bombay Rock in order to identify with an alternative and international music-based youth culture rather than the localised, beach-oriented one that was more stereotypical of her hometown. In her words, 'While my schoolmates were bobbing beyond the breakers on salty surfboards, I was huddled in a darkened room listening to music' (2012: 7). Since many of these venues no longer exist, one can find numerous online discussion forums and blogs today that are devoted to the memories of these spaces and what they had to offer young people.

One chat stream from a website called Australian Music History illustrates this point as well as a desire to 'reanimate' such spaces - if only virtually. One commenter writes that the Bombay Rock 'was the best venue in the state. Ten dollar nights all you can drink brings back memories, still comes up in conversations with the boys' (Bombay Rock n.d.). Meanwhile, another commentator remembers his band playing there and at other venues around the Gold Coast. He says, 'I was in the first punk band from the Coast called Complete Chaos. Started around 8081. Changed name to N-Zone. Used to play Bombay, Patch, Playroom ... all the spots'. Another discussion forum on The Lonely Planet website is also full of references to Bombay Rock as part of the Gold Coast's unique history. One contributor to the discussion writes, 'Born and bred [in the Gold Coast], there were many icons that gave it a unique sense of character ... Let's see if you remember these.' He then includes the Bombay Rock and Tara Village nightclubs at Surfers as places popular with young people, alongside skating rinks and pinball arcades (The Gold Coast n.d.). Finally, there is a discussion forum on the Australian music website Mess+Noise called 'Long Lost Venues', whose users express nostalgia for 
these spaces that provided identity-shaping experiences during their younger years. The moderator of this forum solicits like-minded Gen-Xers by writing, 'Post me if you frequented this iconic venue [Bombay Rock] ... would love to find out ... $\&$ let me know what band you saw.' A message from another respondent reflects both nostalgia for such venues and frustration with the fact that they no longer exist: The respondent states, 'the Bombay Rock was a blistering venue in the $80 \mathrm{~s}$ in Surfers Paradise ... long gone ... Playroom as mentioned [also] levelled ... the Jet Club which hosted the residents in Collangatta [sic] of all places closed in the 80s ... maybe the Kirra Beach Hotel [is still open?] ... this why I left [the Gold Coast]' (Lost Lost Venues 2007).

Although these memories of Bombay Rock and other influential clubs from the 1980s point again to the idea that the Gold Coast was and is mostly a site of youth culture consumption rather than production, the mention of local bands such as punk group N-Zone hints at the fact that the city was also evolving into a centre for independent music production and music scenes by this time. Chris Driver (2011: 975), for instance, attests to a now-robust hardcore punk scene on the Gold Coast, while touring festivals like the Big Day Out have offered a 'Local Artists Stage' to up-and-coming bands. In 2012, through a competition sponsored by the A Venue program, six Gold Coast acts were selected to play this local stage. As an initiative co-founded by the Gold Coast City Council and Arts Queensland, A Venue demonstrates that local music production has been on the rise. The Arts Queensland web page describes the program as a way to 'assist young emerging musicians aged between 15 and 30 to develop their skills and professional opportunities in the music industry'. However, the name of the program itself also stresses the importance that music spaces have for musicians and audiences alike. In this regard, the Gold Coast, with its ever-evolving selection of nightclubs, remains true to its history as a city that provides key spaces for both local and out-of-town youth to experience live music and the various scenes that accompany it (A Venue 2012).

\section{New possibilities for heritage tourism}

One of the most challenging aspects of cultivating popular music heritage and tourism based on the Gold Coast's past is the fact that many of these once-beloved venues no longer exist. However, such tourism elsewhere faces similar challenges, and often relies on imaginative narratives rather than the actual objects or spaces themselves. Robert J. Kruse (2005: 106) describes this phenomenon as it relates to his experiences of a Beatles walking tour in London. Such interactions prompt an 'internal tour of memory [where] a vicarious landscape ... is far richer and personal than the "real landscape". Arguably, this kind of heritage tourism attracts travellers who both embrace personal nostalgia and are what Joanne Mackeller (2009) describes as 'fixated consumer[s]'. In her study of what she calls 'serious participants' at the rockabilly Wintersun festival, she realises that many of these people have come to Coolangatta not only due to the city's year-round attractions, but because it is also where the rockabilly crowd had chosen to assemble and reimagine 1950s culture (2009: 86). In this sense, the people who might identify as 'popular music travellers' are those whose touristic choices are geared toward musically oriented sites of every conceivable genre and time period. These travellers 
interact with cities like the Gold Coast as a form of self-actualisation or identityconstruction. In terms of discussions surrounding 'heritage', the existence of such travellers and consumers underscores the nature of postmodern tourism, which is fragmented and is often 'emphasizing the subjectivities, vested interests and contestations inherent in the identification, presentation and interpretation of 'heritage' by multiple stakeholders' (Weaver 2009: 249).

Though a number of former Gold Coast venues have been torn down or closed, there are several possibilities for how this kind of tourism could operate. Conceivably, a music-oriented walking tour along Surfers' Cavill Avenue would satisfy the popular music traveller as a flâneur (Wood 2005). Such a tour could either be conducted by local historians or be an audio-led, do-it-yourself walking tour. In the second option, a collection of oral history 'music memories' spanning from the 1960 s to the present would play at key sites. In between the recorded monologues, tourists would be able to listen to fitting music from each era. There are currently such walking tours available via downloadable mp3s for many cities around the world, but they usually do not focus on popular music history per se. One exception is a hip hop audio tour through the Bronx via a company called 'Soundwalk'. Its website promotes the tour as follows: 'MC your way past Afrika Bambaataa's aura, rappin' out hot joints, old school joints, when rap was not yet hip-hop'. Press surrounding this tour has been positive, with one reviewer from the Washington Post proclaiming, 'This is the way I want to see a city' (The Bronx n.d.). With this sort of immersive tour, personal memories connected to music set the tone for one's understanding of space and place.

Another idea is that given the past success of the Wintersun festival in Coolangatta, it makes sense that a 1960 s-themed festival might be fitting now that Wintersun has moved to another location. It is easy to imagine a mix of 1960s beat and surf music played, participants dressed in era-appropriate attire and stalls available with the decade's collectibles. The location is ideal because the vibrant music history and youth culture of this time period coincide with the rampant and often literally sky-high growth of the Gold Coast itself. The Surfers Paradise mod-style QT Hotel could serve as a venue for both DJ-ed events and concerts included in such a festival.

Such cultural offerings would not just expand the city's tourist options, but would also remind locals that their city has a history beyond that suggested by gold bikini-clad meter maids and surfing competitions. Certainly, such ventures would necessitate the support of local government. Though the city's unique youth culture heritage does not yet inform tourism as much as it could, some acknowledgement of this history was given by David Power, who ran for mayor in 2012. During his campaign, Power stated that it would be important to '[e]ncourage the establishment of live music venues in Surfers Paradise with the removal of all fees and charges for an application to encourage the restoration of Surfers as a live music venue reflecting the era of Bombay Rock and other great venues' (Platinum Nightclub 2012). Since live music has long been part and parcel of the Gold Coast's youth culture 'experience', it is apparent that a rich aspect of its history has not yet been explored fully. The city - and especially Surfers Paradise - is often too unfairly derided as kitschy and lacking in 'real history'. However, this critique is based on narrow and passé assumptions about history and heritage. Like Las Vegas and other 'new cities' around the globe (Mullins 1990), the Gold Coast has 
great potential to revel in the splendour of its vivid, modernist heritage - one that includes a dynamic history of youth culture driven by the irreverent and joyous beat of rock'n'roll.

\section{References}

Arrow M. 2009. Friday on our minds: popular culture in Australia since 1945. Sydney: UNSW Press.

A Venue 2012. 'Queensland grants program promoting young musicians'. http://www.arts.qld.gov.au/policy/a-venue.html.

Baker S., Bennett A. and Wise P. 2012. 'Living the "strip": Negotiating neighbourhood, community, and identity on Australia's Gold Coast'. In C. Richardson and H.A. Skott-Myhre (eds), Habitus of the hood, Chicago: University of Chicago Press, pp. 95-120.

Baker G.A. 1987. Australian made: Gonna have a good time tonight. Sydney: HarperCollins.

Beesley L. 2005. The potential role of cultural tourism on the Gold Coast. Gold Coast: Sustainable Tourism CRC.

Bennett A. 2009. 'Heritage rock': Rock music, representation and heritage discourse. Poetics 37(5-6): 474-89.

Bombay Rock Surfers Paradise n.d. Comments about the defunct Gold Coast nightclub. http://australianmusichistory.com/bombay-rock-surfers-paradise/\#comment-2936.

The Bronx: Bronx River - hip hop walk n.d. Description of self-guided hip hop tour. http://www.soundwalk.com/\#/TOURS/bronxhiphop.

Buckridge P. 2012. Interviewed with author, 29 May.

Burton P. 2012. 'Growing pains: adolescent urbanism on the Gold Coast'. Geodate 25(2): 8-11.

Che D. 2009. 'Techno: Music and entrepreneurship in Post-Fordist Detroit'. In O. Johansson and T.L. Bell (eds), Sound, society and the geography of popular music. Farnham: Ashgate, pp. 261-80.

The Church 2010. ARIA Hall of Fame acceptance speech. Online video. https://www.youtube.com/watch?v=97p7t_FaNiw.

Clark T. 2007. The indie city: Why Portland is America's indie rock mecca. Slate, 11 September. http://www.slate.com.

Cohen S. 1991. Rock culture in Liverpool: Popular music in the making. Oxford: Clarendon Press.

Cohen S. 2007. Decline, renewal and the city in popular music culture: Beyond the Beatles. Farnham: Ashgate.

Cohen S. 2013. 'Musical memory, heritage and local identity: Remembering the popular music past in a European Capital of Culture'. International Journal of Cultural Policy 19(5): 576-94.

Connell J. and Gibson C. 2002. Sound tracks: Popular music, identity and place. London: Routledge.

Coupland D. 1991. Generation X: Tales for an accelerated culture. New York: St Martin's Press.

The Creatures n.d. Brief history of an Australian band. http://www. musicminder.com/scripts/entertainers/displayentertainer.asp?ID=008125. 
Cross C.R. 2011. 'EMP SFM Nirvana exhibit recalls once-in-a-lifetime moment'. Seattle Times, 9 April. http://www.seattletimes.com.

Driver C. 2011. 'Embodying hardcore: rethinking subcultural identities'. Journal of Youth Studies 14(8): 975-90.

Evers C. 2009. “"The Point”: Surfing, geography and a sensual life of men and masculinity on the Gold Coast, Australia'. Social and Cultural Geography 10(8): 893-908.

Farwell G. 1970. Sun country. Melbourne: Nelson.

Feldman C.J. 2009. 'We are the Mods': A transnational history of a youth subculture. New York: Peter Lang.

The Gold Coast - Northern End 2012. Comments about life on the Gold Coast in the 70s and 80s. https://www.lonelyplanet.com/thorntree/forums/australasiapacific-australia-new-zealand-antarctica/topics/the-gold-coast-northern-end.

Gough A. 2014. 'Before Brissie's nightlife was cool'. Courier-Mail, 26 September. http://www.couriermail.com.au.

Griffin G. 1998. 'The good, the bad and the peculiar: Cultures and policies of urban planning and development on the Gold Coast'. Urban Policy and Research 16(4): 285-92.

Halasz P. 1967. A swinger's guide to London. New York: Coward-McCann.

Jacobson M. 2009. 'Born to be wild.' Gold Coast Bulletin, 23 May, p. 4.

Johansson O. and Bell T.L. (eds) 2009. Sound, society and the geography of popular music. Farnham: Ashgate.

King S.A. and Foster R.P. 2001. “No problem, mon”: Strategies used to promote reggae music as Jamaica's cultural heritage'. Journal of Nonprofit and Public Sector Marketing 8(4): 3-16.

Kruse R.J. III. 2005. 'The Beatles as place makers: Narrated landscapes in Liverpool, England'. Journal of Cultural Geography 22(2): 87-114.

Kugel S. 2008. 'Rock around the block'. New York Times, 3 February. http://www.newyorktimes.com.

Live music venues on the Gold Coast 2015. A listing of current music venues, July. http://www.goldcoastaustralia.com/gold-coast-live-music.html.

Long lost venues 2007. Discussion forum about nightclubs that have closed. http://betam.messandnoise.com/discussions/391916.

Mackellar J. 2009. 'An examination of serious participants at the Australian Wintersun festival'. Leisure Studies 28(1): 85-104.

Marks I.D. and McIntyre I. 2011. Wild about you! The sixties beat explosion in Australia and New Zealand. Portland, OR: Verse Chorus Press.

McIntyre I. 2006. Tomorrow is today: Australia in the psychedelic era, 1966-1970. Adelaide: Wakefield Press.

McWatters N. 2012. One way or another: The story of a girl who loved rock stars. Melbourne: Black Inc.

Mullins P. 1990. 'Tourist cities as new cities'. Australian Planner 28(3): 37-41.

Nayak A. 2003. Race, place \& globalization: Youth cultures in a changing world. Oxford: Berg.

Platinum Nightclub David Power thread 2012. Facebook mayoral endorsement. https://www.facebook.com/permalink.php?story_fbid=10150605389147289\&id= 68014977288. 
Poria Y., Butler R. and Airey D. 2001. 'Clarifying heritage tourism'. Annals of Tourism Research 2(4): 1047-49.

Reynolds S. 2011. Retromania: Pop culture's addiction to its own past. New York: Faber \& Faber.

Romig K. 2009. 'A listener's mental map of California'. In O. Johansson and T.L. Bell (eds), Sound, society and the geography of popular music. Farnham: Ashgate, pp. 107-26.

Skelton T. and Valentine G. 1996. Cool places: Geographies of youth culture. London: Routledge.

Stafford A. 2004, Pig city: From the Saints to Savage Garden. Brisbane: University of Queensland Press.

Stalking Seattle: A Rock \& Roll Sightseeing Tour n.d. Home page. http://stalkingseattletours.blogspot.com.au.

Stoltz G. 2013. 'Gold Coast icons such as Miami Ice the focus of social media campaigns to halt development'. Courier-Mail, 17 August. http://www.couriermail.com.au.

Stratton J. 1992. The young ones: Working-class culture, consumption and the category of youth. Perth: Black Swan Press.

Weaver D.B. 2011. 'Contemporary tourism heritage and heritage tourism: Evidence from Las Vegas and the Gold Coast'. Annals of Tourism Research 38(1): 249-67.

Whiteley S., Bennett A. and Hawkins S. 2005. Music, space and place: popular music and cultural identity. Farnham: Ashgate.

Wind and Sea by the Sunsets 2011. Description of a 1960s song and band. http://garage60s.blogspot.com.au.

Wood A.F. 2005. 'What happens [in "Vegas"]: Performing the post-tourist flâneur in "New York" and "Paris". Text and Performance Quarterly 25(4): 315-33.

Zion L. 1987. 'The impact of the Beatles on pop music in Australia: 1963-66'. Popular Music 6(3): 291-311. 